\title{
Fluoribacter dumoffii (Brenner et al.) comb. nov. and Fluoribacter gormanii (Morris et al.) comb. nov.
}

\author{
A. BROWN, ${ }^{1-5}$ G. M. GARRITY, ${ }^{2,5}$ AND R. M. VICKERS ${ }^{2}$ \\ Medical, ${ }^{1}$ Laboratory, ${ }^{2}$ and General Medical Research ${ }^{3}$ Services, Veterans Administration Medical Center, \\ Pittsburgh, Pennsylvania 15240; and School of Medicine ${ }^{4}$ and Graduate School of Public Health, ${ }^{5}$ \\ University of Pittsburgh, Pittsburgh, Pennsylvania 15213
}

\begin{abstract}
Strains of "atypical Legionella-like organisms" (ALLO) were studied by deoxyribonucleic acid homology. Strains WIGA $\left(\mathrm{ALLO}_{1}\right)$ and MI-15 $\left(\mathrm{ALLO}_{2}\right)$ were previously shown by Garrity et al. (G. M. Garrity, A. Brown, and R. M. Vickers, Int. J. Syst. Bacteriol. 30:609-614, 1980) to be related, and the name Fluoribacter bozemanae was proposed for them. We now show that strains NY$23\left(\mathrm{ALLO}_{4}\right)$ and TEX-KL are also closely related genetically. Studies with strain LS-13 demonstrate a lower, but significant, degree of homology of LS-13 with strains WIGA, MI-15, and NY-23, justifying inclusion of all of these strains in a single genus, distinct from Legionella. It is proposed, therefore, that because of phenotypic similarities and genetic relatedness, strains NY-23, TEX-KL, and LS13 be classified as members of the genus Fluoribacter, which also includes strains WIGA and MI-15. Because NY-23 and LS-13 are the type strains of Legionella dumoffii and $L$. gormanii, respectively, we propose the transfer of these species to the genus Fluoribacter as $F$. dumoffii (Brenner et al.) comb. nov. and $F$. gormanii (Morris et al.) comb. nov.
\end{abstract}

Since the discovery of Legionella pneumophila, the agent of Legionnaires disease, two other groups of fastidious bacteria have been isolated $(1,7,9,13,19,21,22)$ which share some phenotypic characteristics with L. pneumophila $(6,7,11,13)$. However, deoxyribonucleic acid (DNA) hybridization studies demonstrated no significant homology between these strains and L. pneumophila $(5,8-10,13-15,18)$, thereby excluding relatedness at the genus level. One group contains the strains known as the Pittsburgh pneumonia agent (PPA) $(11,19)$ and the TATLOCK strain $(9,11,21)$, for which three scientific names, Legionella micdadei, L. pittsburghensis (18), and Tatlockia micdadei (8), have been proposed. Members of the second group are serologically more diverse $(7,13)$ and have been referred to as atypical Legionella-like organisms (ALLO) (7). Two of these bacteria (WIGA and MI-15) appear to share common antigenic determinants by the direct immunofluorescence antibody technique (7) and have been shown to be genetically related at the species level $(5,8)$. We proposed the name Fluoribacter bozemanae for these two isolates (8), whereas the name Legionella bozemanii [sic] was proposed by Brenner and co-workers (5). In our previous paper, we presented DNA homology data for WIGA $\left(\mathrm{ALLO}_{1}\right)$, MI-15 $\left(\mathrm{ALLO}_{2}\right)$, and NY-23 $\left(\mathrm{ALLO}_{4}\right)(8)$. In this paper, we now present data for two other members of this group, LS-13 $\left(\mathrm{ALLO}_{3}\right)$ (7) and TEX-KL (13), data which clarify the relationship between these organisms.

\section{MATERIALS AND METHODS}

Bacteria. The bacterial strains used in this study are listed in Table 1. Methods of stock maintenance, media preparation, inoculation, and incubation have been previously described (8).

Preparation of DNA. For preparing DNA, a modification of the method of Brenner et al. (3) was used, as previously described (8). Briefly, late-log-phase bacteria were harvested and digested with proteinase $\mathrm{K}$ $(80 \mu \mathrm{g} / \mathrm{ml})$ and $0.2 \%(\mathrm{wt} / \mathrm{vol})$ sodium dodecyl sulfate overnight at $37^{\circ} \mathrm{C}$. Lysis was completed by increasing the sodium dodecyl sulfate concentration to $1 \%$ (wt/ vol) and raising the temperature to $65^{\circ} \mathrm{C}$. The lysed culture was then extracted with an equal volume of phenol-chloroform-isoamyl alcohol (24:24:1). The DNA in the aqueous phase was precipitated by the addition of $80 \mathrm{ml}$ of $95 \%$ ethanol, resuspended in $5 \mathrm{ml}$ of $0.1 \times \mathrm{SSC}$ (saline citrate; $1 \times \mathrm{SSC}$ is $0.15 \mathrm{M} \mathrm{NaCl}$ plus $0.015 \mathrm{M}$ sodium citrate, $\mathrm{pH} 7.0$ ), and digested with deoxyribonuclease-free ribonuclease $(50 \mu \mathrm{g} / \mathrm{ml})$ for $30 \mathrm{~min}$ at $37^{\circ} \mathrm{C}$ and then proteinase $\mathrm{K}(40 \mu \mathrm{g} / \mathrm{ml})$ for $2 \mathrm{~h}$. Samples were reextracted once with phenolchloroform-isoamyl alcohol and twice with chloroform-isoamyl alcohol (24:1). After re-precipitation with $80 \mathrm{ml}$ of $95 \%$ ethanol, the DNA precipitate was washed sequentially with 70 and $90 \%$ ethanol and redissolved in $10 \mathrm{mM}$ tris(hydroxymethyl)aminomethane (pH 7.2)-1 $\mathrm{mM}$ ethylenediaminetetraacetate at $25^{\circ} \mathrm{C}$.

Thermal denaturation studies. The guanineplus-cytosine $(\mathrm{G}+\mathrm{C})$ content of the Fluoribacter DNA 
TABLE 1. Strains used in this study

\begin{tabular}{|c|c|c|c|}
\hline $\begin{array}{l}\text { Laboratory } \\
\text { designation }\end{array}$ & Name & Strain & Received from \\
\hline LDB 1 & Legionella pneumophila & Philadelphia 1 (ATCC 33152) & $\mathrm{CDC}^{a}$ \\
\hline LDB 2 & L. pneumophila & Bellingham & $\mathrm{CDC}$ \\
\hline LDB 4 & L. pneumophila & Knoxville 1 (ATCC 33153) & CDC \\
\hline LDB 5 & L. pneumophila & Pontiac & CDC \\
\hline LDB 6 & L. pneumophila & VAMC-L8W & $\mathrm{VA}^{b}$ \\
\hline TAT & Tatlockia micdadei & TATLOCK (ATCC 32218) & $\mathrm{CDC}$ \\
\hline PPA 1 & T. micdadei & PPA/EK (ATCC 33204) & $\mathrm{AWP}^{c}$ \\
\hline PPA 2 & T. micdadei & PPA/LR & AWP \\
\hline PPA 3 & T. micdadei & VAMC-PGH 12 (ATCC 33364) & CDC, VA \\
\hline PPA 4 & T. micdadei & PPA/CRES & AWP \\
\hline WIGA & $\begin{array}{l}\text { Fluoribacter bozemanae } \\
\quad(\text { L. bozemanii })\end{array}$ & WIGA (ATCC 33217) & $\mathrm{AWP}, \mathrm{LBC}^{d}$ \\
\hline MI-15 & F. bozemanae & MI-15 & AWP, LBC \\
\hline LS-13 & Unclassified & LS-13 (ATCC 33342) & AWP, LBC \\
\hline NY-23 & Unclassified (L. dumoffii) & NY-23 (ATCC 33279) & AWP, LBC \\
\hline TEX-KL & Unclassified & TEX-KL (ATCC 33343) & AWP, LBC \\
\hline EC-1 & Escherichia coli & VAMC-EC1 & VA \\
\hline
\end{tabular}

${ }^{a}$ CDC, Center for Disease Control, Atlanta, Ga.

${ }^{b}$ VA, Veterans Administration Medical Center, Pittsburgh, Pa.

${ }^{c}$ AWP, A. W. Pasculle, Presbyterian-University Hospital, Pittsburgh, Pa.

${ }^{d}$ LBC, L. B. Cordes, Center for Disease Control, Atlanta, Ga.

was determined spectrophotometrically as previously described (8).

Preparation of radioactively labeled DNA. Bacterial DNA was labeled with $\left[\alpha-{ }^{32} \mathrm{P}\right]$ deoxycytidine 5 '-triphosphate (specific activity, 500 to $750 \mathrm{Ci} / \mathrm{mmol}$ ) by the nick translation method of Rigby et al. (20). Nick translation reagents were obtained from $\mathrm{Be}$ thesda Research Laboratories, Rockville, Md. Labeled DNA was separated from unincorporated substrate by chromatography on a column of Sephadex G-50 fine $(1$ by $15 \mathrm{~cm}$ ) equilibrated in $10 \mathrm{mM}$ tris(hydroxymethyl)aminomethane at $\mathrm{pH} 8.0\left(25^{\circ} \mathrm{C}\right)$. Probe DNA prepared in this manner had an average specific activity exceeding $8 \times 10^{7} \mathrm{cpm} / \mu \mathrm{g}$.

DNA reassociation. Heat-denatured bacterial DNA $(8 \mu \mathrm{g})$ prepared from each test strain was added to radioactive probe DNA $(0.29 \mathrm{ng})$ in $100 \mu \mathrm{l}$ of $0.28 \mathrm{M}$ phosphate buffer (an equimolar amount of monobasic and dibasic sodium phosphate). Optimal conditions of reassociation were obtained by incubation of this mixture for $96 \mathrm{~h}$ at $64^{\circ} \mathrm{C}$, at which time more than $85 \%$ of the labeled, input DNA had reannealed to homologous unlabeled DNA. To test for the extent of nucleotide mismatching between hybridized segments, DNA reannealing was also performed at $75^{\circ} \mathrm{C}$. At $96 \mathrm{~h}$, single- and double-stranded DNAs were separated by a modification of the batch hydroxyapatite method of Brenner et al. $(3,4,8)$. Controls for self-annealing of the labeled probe DNA showed generally less than $5 \%$ of the reannealing observed in reactions containing an excess $(27,500$-fold) of homologous unlabeled DNA. These background values were subtracted from all test samples.

The degree of relatedness between organisms is expressed as the amount of DNA bound to hydroxy- apatite in heterologous reactions as compared with that observed in homologous reactions (100\%). Values for each hybridization reaction represent the average of at least four experimental measurements at each temperature.

\section{RESULTS}

The results of hybridization studies using DNA from the ALLO strains are presented in Table 2. Values represent the extent of hybrid formation in reciprocal reactions at 64 and $75^{\circ} \mathrm{C}$.

The greatest base sequence homologies were observed between TEX-KL and NY-23 and between WIGA and MI-15 at $64^{\circ} \mathrm{C}$. Furthermore, the extent of hybridization was essentially unchanged when reannealing was done at the more restrictive temperature $\left(75^{\circ} \mathrm{C}\right)$.

Less homology was seen in the other reactions. With three of the combinations tested (LS-13 and MI-15, LS-13 and WIGA, and LS-13 and NY-23), homology ranged from 22 to $34 \%$. In the hybridization reactions with DNA from NY-23 and either WIGA or MI-15, 14 to $22 \%$ of the labeled DNA was found to reanneal. The least homology in this group was observed between TEX-KL and either MI-15 or LS-13. In contrast to the reactions of TEX-KL and NY-23 and of WIGA and MI-15 reactions, which demonstrate a high degree of homology at both reaction temperatures, the other combinations exhibited low thermal stability as evidenced by signifi- 
TABLE 2. DNA homology between the ALLO strains

\begin{tabular}{|c|c|c|c|c|c|c|c|c|c|c|}
\hline \multirow{3}{*}{ Source of unlabeled DNA } & \multicolumn{10}{|c|}{ Relative $\%$ of reannealing obtained with the following source of labeled DNA: } \\
\hline & \multicolumn{2}{|c|}{ WIGA } & \multicolumn{2}{|c|}{ MI-15 } & \multicolumn{2}{|c|}{ LS-13 } & \multicolumn{2}{|c|}{ NY-23 } & \multicolumn{2}{|c|}{ TEX-KL } \\
\hline & $64^{\circ} \mathrm{C}^{a}$ & $75^{\circ} \mathrm{C}^{a}$ & $64^{\circ} \mathrm{C}$ & $75^{\circ} \mathrm{C}$ & $64^{\circ} \mathrm{C}$ & $75^{\circ} \mathrm{C}$ & $64^{\circ} \mathrm{C}$ & $75^{\circ} \mathrm{C}$ & $64^{\circ} \mathrm{C}$ & $75^{\circ} \mathrm{C}$ \\
\hline WIGA & $100^{b}$ & 100 & 77 & 81 & 33 & 10 & 14 & 2 & 16 & 8 \\
\hline MI-15 & 74 & 76 & 100 & 100 & 34 & 7 & 15 & 2 & 5 & 7 \\
\hline LS-13 & 28 & 3 & 28 & 3 & 100 & 100 & 22 & 3 & 9 & 7 \\
\hline NY-23 & 16 & 2 & 22 & 1 & 25 & 6 & 100 & 100 & 91 & 94 \\
\hline TEX-KL & 7 & 5 & 8 & 4 & 4 & 6 & 94 & 88 & 100 & 100 \\
\hline
\end{tabular}

${ }^{a}$ Temperature of reannealing reaction.

${ }^{b}$ Homologous reactions have been normalized to $100 \%$. Values are averaged from three to four individual experiments, with duplicate reactions in each experiment.

cantly less reannealing at $75^{\circ} \mathrm{C}$ compared with that at $65^{\circ} \mathrm{C}$.

Studies with DNA from LS-13 and several $L$. pneumophila isolates demonstrated approximately $12 \%$ homology; in reactions with LS-13 and isolates of T. micdadei, an average of $6 \%$ homology was seen. The DNA of other ALLO strains showed no significant homology above background reannealing when reacted with DNA from L. pneumophila or T. micdadei, nor was significant homology seen between $L$. pneumophila and T. micdadei (8).

\section{DISCUSSION}

ALLOs are quite similar to $L$. pneumophila and T. micdadei with respect to their morphology and fastidious growth requirements. These organisms may be distinguished by several phenotypic differences (8). The colonies of all ALLO strains identified so far demonstrate an intense blue-white fluorescence when exposed to longwave ultraviolet light $(7,8,13,22)$. In addition, ALLO strains can be distinguished from L. pneumophila and $T$. micdadei by differences in branched-chain fatty acid composition $(7,9,13$, $16,17)$, by immunological methods (9), and by the absence of oxidase activity (9). Like $L$. pneumophila, the five Fluoribacter strains hydrolyzed starch, produced a brown pigment on charcoal-free buffered yeast extract agar containing $2.5 \mathrm{mM}$ tyrosine, and possessed gelatinase activity; $T$. micdadei did not exhibit any of these activities (8).

In general, members of a species have been found to exhibit at least 70\% DNA homology under optimal conditions for reannealing $(2,12)$; in addition, there usually is little difference between the degree of DNA hybrid formation at the optimum temperature and that at the more restrictive reannealing temperature. Genus-level relationships are characterized by much lower levels of DNA homology in the range of 20 to $60 \%$ (12). In addition, one frequently observes a large decrease in the thermal stability of the hybrid DNA molecules formed when more distantly related organisms are studied by this technique; this is due to the presence of unpaired nucleotides in the hybrid (2).

We recently reported the results of DNA homology studies with several strains of $L$. pneumophila and the previously unclassified organisms PPA/TATLOCK and three ALLO strains (WIGA, MI-15, and NY-23). The PPA/TATLOCK strains were grouped as a single species, T. micdadei, and for WIGA and MI-15, the name $F$. bozemanae was proposed.

The results of this study show a high level of DNA homology between NY-23 and TEX-KL, suggesting a species-level relationship. Although LS-13 is more distantly related to the other ALLO strains, it occupies a position between WIGA/MI-15 and NY-23/TEX-KL in the genus Fluoribacter, with a sufficient degree of homology to justify considering this group as a single genus. Unlike the other Fluoribacter strains, LS-13 also demonstrates a low, but consistent, degree of homology with both L. pneumophila and T. micdadei.

In spite of the extremely close relationship between TEX-KL and NY-23, the degree of homology between the DNA of TEX-KL and that of either MI-15 or LS-13 (5 and 8\% and 9 and $4 \%$, respectively, for reciprocal reactions) is much less than that observed between NY-23 and these isolates (14 and $22 \%$ and 15 and $25 \%$, respectively, for reciprocal reactions). This suggests that MI-15 and LS-13 have small areas of homology within the region common to TEX$\mathrm{KL}$ and NY-23 and essentially complete homology to that segment unique to NY-23 (approximately $10 \%$ of the genome). Although this hypothesis is consistent with the data, it is also possible that some strains possess multiple copies of some genetic segments. Further studies to characterize common sequences are in progress and may lead to the construction of crude genetic maps.

Since this manuscript was submitted for pub- 
lication, two papers have appeared in which were proposed the names Legionella bozemanii [sic] for WIGA (type strain) and MI-15 (5), L. dumoffii for NY-23 (type strain) and TEX-KL (5), and L. gormanii for LS-13 (type strain) (15). Significant phenotypic differences (8), as well as differences in DNA G+C content (8) and DNA hybridization data, argue strongly that these organisms do not belong in the same genus as $L$. pneumophila. Therefore, we propose that these organisms be transferred to the genus Fluoribacter, a taxon we previously proposed to include $F$. bozemanae, whose type strain is WIGA (ATCC 33217). Therefore, L. dumoffii becomes $F$. dumoffii (Brenner et al.) comb. nov., and $L$. gormanii becomes $F$. gormanii (Morris et al.) comb. nov. The type strain of $F$. dumoffii is NY23 (ATCC 33279), and that of $F$. gormanii is LS13 (ATCC 33342). The argument that these organisms belong to the genus Fluoribacter is supported by phenotypic similarities and the DNA relatedness between the type strains.

All Fluoribacter species are gram-negative rods, 0.5 to 0.7 by 4.0 to $5.0 \mu \mathrm{m}$, with short filaments (up to $\sim 25 \mu \mathrm{m}$ ) and have similar growth characteristics. Strain LS-13 forms slightly longer filaments (up to $50 \mu \mathrm{m}$ ) than do the other strains examined. All demonstrate colony fluorescence under ultraviolet illumination. The $\mathrm{G}+\mathrm{C}$ content of the DNAs of these organisms is $40.7 \pm 0.7 \mathrm{~mol} \%$ (8); the values for individual Fluoribacter strains do not differ significantly from this average. $F$. gormanii and $F$. dumoffii slightly darken charcoal-free yeast extract agar, unlike $F$. bozemanae, which produces pigment only when the medium is supplemented with $2.5 \mathrm{mM}$ tyrosine.

\section{ACKNOWLEDGMENTS}

We thank Richard A. Consigli for critically reviewing this manuscript and Monto Ho, Robert Yee, Elaine Elder, and Victor Yu for their helpful discussions. We also thank Donna Williams for her expert secretarial assistance.

This work was supported by the Veterans Administration General Medical Research Service.

\section{REPRINT REQUESTS}

Address reprint requests to: Dr. Arnold Brown, Chief, Infectious Disease and Microbiology Sections, VA Medical Center, University Drive C, Pittsburgh, PA 15240.

\section{LITERATURE CITED}

1. Bozeman, F. M., J. W. Humphries, and J. M. Campbell. 1968. A new group of rickettsia-like agents recovered from guinea pigs. Acta Virol. 12:87-93.

2. Brenner, D. J. 1973. Deoxyribonucleic acid reassociation in the taxonomy of enteric bacteria. Int. J. Syst. Bacteriol. 23:298-307.

3. Brenner, D. J., G. R. Fanning, K. E. Johnson, R. V.
Citarella, and S. Falkow. 1969. Polynucleotide sequence relationships among members of Enterobacteriaceae. J. Bacteriol. 98:637-650.

4. Brenner, D. J., G. R. Fanning, A. V. Rake, and K. E. Johnson. 1969. Batch procedures for thermal elution of DNA from hydroxyapatite. Anal. Biochem. 28:447459.

5. Brenner, D. J., A. G. Steigerwalt, G. W. Gorman, R. E. Weaver, J. C. Feeley, L. G. Cordes, H. W. Wilkinson, C. M. Patton, B. M. Thomason, and $K$. R. Lewallen-Sasseville. 1980. Legionella bozemanii species nova and Legionella dumoffii species nova: classification of two additional species of Legionella associated with human pneumonia. Curr. Microbiol. 4: 115-120.

6. Brenner, D. J., A. G. Steigerwalt, and J. E. McDade. 1979. Classification of the Legionnaires' disease bacterium: Legionella pneumophila, genus novum, species nova, of the Family Legionellaceae, familia nova. Ann. Intern. Med. 90:656-658.

7. Cordes, L. B., H. W. Wilkinson, G. W. Gorman, B. J. Fikes, and D. W. Fraser. 1979. Atypical legionellalike organisms: fastidious water-associated bacteria pathogenic for man. Lancet ii:927-930.

8. Garrity, G. M., A. Brown, and R. M. Vickers. 1980. Tatlockia and Fluoribacter: two new genera of organisms resembling Legionella pneumophila. Int. J. Syst. Bacteriol. 30:609-614.

9. Hebert, G. A., C. W. Moss, L. K. McDougal, F. M. Bozeman, R. M. McKinney, and D. J. Brenner. 1980. The rickettsia-like organisms TATLOCK (1943) and HEBA (1959): bacteria phenotypically similar, but genetically distinct from Legionella pneumophila and the WIGA bacterium. Ann. Intern. Med. 92:45-52.

10. Hebert, G. A., A. G. Steigerwalt, and D. J. Brenner. 1980. Legionella micdadei species nova: classification of a third species of Legionella associated with human pneumonia. Curr. Microbiol. 3:225-257.

11. Hebert, G. A., B. M. Thomason, P. P. Harris, M. D. Hicklin, and R. M. McKinney. 1980. "Pittsburgh pneumonia agent": a bacterium phenotypically similar to Legionella pneumophila and identical to the TATLOCK bacterium. Ann. Intern. Med. 92:53-54.

12. Isenberg, H. D. 1979. Microbiology of Legionnaires' disease bacterium. Ann. Intern. Med. 90:502-505.

13. Lewallen, K. R., R. M. McKinney, D. J. Brenner, C. W. Moss, D. H. Dail, B. M. Thomason, and R. A. Bright. 1979. A newly identified bacterium phenotypically resembling, but genetically distinct from, Legionella pneumophila: an isolate in a case of pneumonia. Ann. Intern. Med. 91:831-834.

14. McDade, J. E., D. J. Brenner, and F. M. Bozeman. 1979. Legionnaires' disease bacterium isolated in 1947. Ann. Intern. Med. 90:659-661.

15. Morris, G. K., A. G. Steigerwalt, J. C. Feeley, E. S. Wong, W. T. Martin, C. M. Patton, and D. J. Brenner. 1980. Legionella gormanii sp. nov. J. Clin. Microbiol. 12:718-721.

16. Moss, C. W., and S. B. Dees. 1979. Cellular fatty acid composition of WIGA: a rickettsia-like agent similar to the Legionnaires' disease bacterium. J. Clin. Microbiol. 10:390-391.

17. Moss, C. W., R. E. Weaver, S. B. Dees, and W. B. Cherry. 1977. Cellular fatty acid composition of isolates from Legionnaires' disease. J. Clin. Microbiol. 6:140143.

18. Pasculle, A. W., J. C. Feeley, R. J. Gibson, L. G. Cordes, R. L. Myerowitz, C. M. Patton, G. W. Gorman, C. L. Carmack, J. W. Ezzell, and J. N. Dowling. 1980. Pittsburgh pneumonia agent: direct isolation from human lung tissue. J. Infect. Dis. 141:727-732.

19. Pasculle, A. W., R. L. Myerowitz, and C. R. Rinaldo. 1979. New bacterial agent of pneumonia isolated from 
renal-transplant recipients. Lancet ii:58-61.

20. Rigby, P. W. J., M. Dieckman, C. Rhodes, and P. Berg. 1977. Labeling deoxyribonucleic acid to high specific activity in vitro by nick translation with DNA polymerase I. J. Mol. Biol. 113:237-251.

21. Tatlock, H. 1944. A rickettsia-like organism recovered from guinea pigs. Proc. Soc. Exp. Biol. Med. 57:95-99.

22. Thomason, G. M., P. P. Harris, M. D. Hicklin, J. A. Blackmon, C. W. Moss, and F. Matthews. 1979. Detection of a Legionella-like bacterium related to WIGA in a fatal case of pneumonia. Ann. Intern. Med. 91:673-676. 